\title{
14
}

\section{Neolithic dispersal implications of murids from late Holocene archaeological and modern natural deposits in the Talaud Islands, northern Sulawesi}

\author{
Julien Louys, Michael Herrera, Stuart Hawkins, Ken Aplin, \\ Christian Reepmeyer, Felicitas Hopf, Stephen C. Donnellan, \\ Sue $0^{\prime}$ Connor and Daud A. Tanudirjo
}

\begin{abstract}
The Sangihe-Talaud Archipelago represents a group of 77 remote islands located between the Philippines and North Sulawesi, in the northern sector of Wallacea. The Talaud Islands have a rich and significant archaeological record going back to the Pleistocene and are instrumental in understanding Pleistocene colonisation of small islands and later models of Austronesian language dispersal. Here we report on vertebrate material excavated from Leang Mande'et, a late Holocene rockshelter on Karakelang, the main island in the Talaud group. The site represents a periodically occupied shelter used for gardening. Fauna recovered predominately comprises murid elements, with at least four taxa (Rattus rattus, Rattus exulans and two Melomys species) found. The rodents show clear signs of being deposited by raptors rather than humans, unlike the small number of fish remains also recovered. DNA sequences from several Rattus rattus specimens are referrable to Rattus rattus complex lineage IV, a lineage with a southern Indochinese origins and broad modern representation through Indonesia and the Philippines. The lack of any Rattus rattus complex lineage II from Leang Mande'et suggests that the first agricultural inhabitants of this island did not come from Taiwan or northern Indochina, but rather that they either originated from the south or that, once established in the Talauds, opened up significant trade networks to the south and in the process acquired a significant pest.
\end{abstract}

Keywords: Black rat, Austronesian migration, Karakelang, ancient DNA 


\section{Introduction}

Commensal rodents represent a strong proxy for the distribution of human settlements and the spread of agricultural practices (Matisoo-Smith and Robins 2004; Aplin et al. 2011; Thomson et al. 2014). Of the various commensal rodents, the Black rat (Rattus rattus sensu lato) is the most widely distributed and arguably the species with greatest past and present impact on human livelihoods. It occurs in disturbed and human-modified landscapes throughout much of the world, typically occupying villages, field complexes and disturbed forests (Aplin et al. 2011). Recent studies of mitochondrial DNA (mtDNA) diversity within the Black rat found multiple, deeply divergent lineages (some of it corresponding with known chromosomal variants; Yosida 1980), particularly within its likely ancestral source area on mainland Asia (Pagés et al. 2010; Aplin et al. 2011). This diversity probably arose through allopatric divergence among populations occupying discrete geographic areas (Aplin et al. 2011) and most likely commenced around 0.18-0.27 Ma (Robins et al. 2008). Aplin et al. (2011) coined the term 'Rattus rattus Complex' $(\mathrm{RrC})$ for the evolutionary unit that includes the various geographic lineages of 'typical' Black rats, as well as two other closely related species. The deep and complex genetic structuring of the $\mathrm{RrC}$ provides excellent opportunities to track patterns of human dispersals and contacts, particularly in response to the emergence and spread of agricultural communities and the operation of maritime trade networks (Aplin et al. 2011).

Two lineages of $R$. rattus are of particular interest in Wallacea, namely the $\operatorname{RrC}$ lineages II and IV. $\mathrm{RrClineage} \mathrm{II} \mathrm{rats} \mathrm{are} \mathrm{thought} \mathrm{to} \mathrm{have} \mathrm{originated} \mathrm{in} \mathrm{northern} \mathrm{Indochina} \mathrm{to} \mathrm{East} \mathrm{Asia,} \mathrm{with} \mathrm{highest}$ haplotype diversity observed in Myanmar, Laos, northern Vietnam and southern China (Aplin et al. 2011). Population expansion analysis of this lineage indicates a relatively recent population increase, beginning during the terminal Pleistocene to early Holocene, while haplotype network analyses indicate a likely dispersal out of Taiwan and flowing through the Philippines and Japan, and from the former into Wallacea and Micronesia (Aplin et al. 2011). RrC lineage IV rats, on the other hand, had a more southern origin, probably around the lower catchment of the Mekong River and potentially on the Sundaic Shelf (Aplin et al. 2011). Population expansion of $\mathrm{RrC}$ lineage IV rats may have been slightly later than that of $\mathrm{RrC}$ lineage II, with dispersal principally through the Sundaic and Wallacean islands but extending to the Philippines in the north and Sri Lanka in the west.

The Sangihe-Talaud Archipelago, a group of 77 tiny and remote islands located between the Philippines and North Sulawesi (Figure 14.1), sits in a strategic geographical location relevant to models describing the initial dispersal routes of Neolithic innovations, and has thus received considerable archaeological attention. In the Blust-Bellwood model of migration dispersal (Blust 1995; Bellwood 2011), the Leang Tuwo Mane'e rockshelter in the Talaud Islands (Bellwood 2007; Tanudirjo 2001) in particular has played a crucial role in determining the age of initial spread of red-slipped pottery and related agricultural groups southwards from northern Island Southeast Asia (ISEA), connecting the Philippines chronologically with later Neolithic sites in Sulawesi, the Moluccas and the Western Pacific (Spriggs 2011).

During the course of new surveys and excavations in the Talaud Islands, we recovered wellpreserved faunal assemblages that included specimens referred to Rattus rattus. Here we describe the stratigraphic context and age of these specimens and present the results of genetic analysis that sheds light on the likely route and timing of dispersal of the commensal Black rat to the Talaud Islands. We discuss the broader implications of the results for understanding Neolithic population movements in the region. 


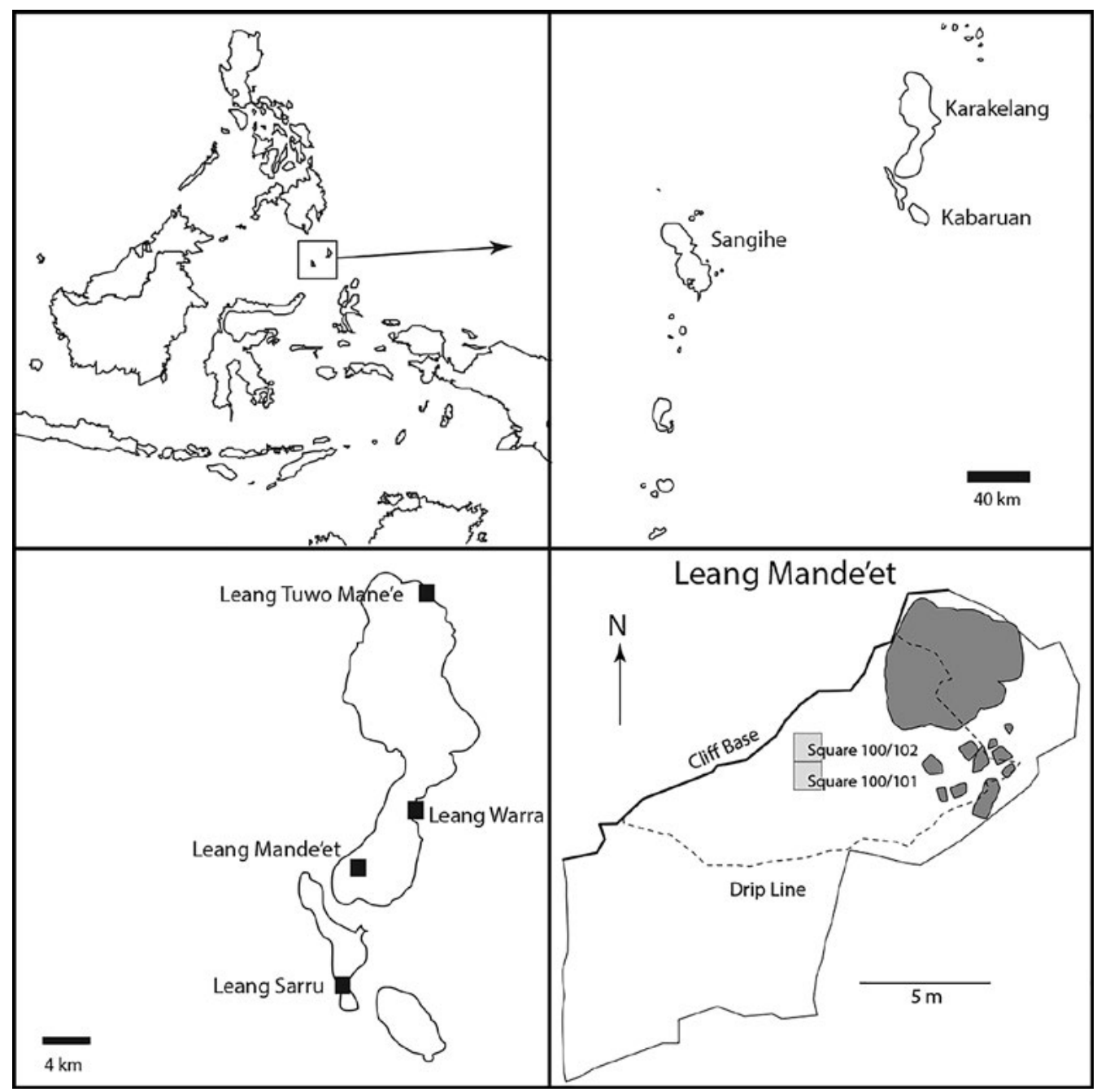

Figure 14.1: Location of the Sangihe-Talaud Archipelago, the major Talaud Islands, and the sites discussed in the text.

Source: Maps prepared by julien Louys.

\section{Methods}

\section{Archaeological excavation}

The Mande'et rockshelter (Leang Mande'et; LMD) is situated on the western side of Karakelang Island, the main island of the Talaud group, about a 45-minute walk upslope of Pampalu village $\left(4^{\circ} 04^{\prime} 32^{\prime \prime} \mathrm{N} 126^{\circ} 42^{\prime} 23^{\prime \prime} \mathrm{E}\right)$. It is a fairly large overhang with a $12 \mathrm{~m}$ opening, depth of $5.5 \mathrm{~m}$ and height at dripline of about $6.5-8 \mathrm{~m}$. It is located at approximately $130 \mathrm{~m}$ elevation with a southeastern aspect. The surface of the shelter is a level, slightly outward sloping area with steep access beyond the shelter. There are recent fire traces on the rock fall and the shelter is currently in use as a resting area for local people. A $2 \mathrm{mx} 1 \mathrm{~m}$ test pit was excavated to a depth of $140 \mathrm{~cm}$ below the datum $(\mathrm{uD})$. Excavations were conducted by trowelling in $10 \mathrm{~cm}$ spits until $140 \mathrm{~cm}$ $\mathrm{uD}$ in square $100 / 101$ and in $5 \mathrm{~cm}$ spits until $30 \mathrm{~cm} \mathrm{uD}$ in square $100 / 102$, and all sediments were wet sieved through a $1.5 \mathrm{~mm}$ mesh sieve. Here, we focus predominately on the faunal remains from this site. 


\section{Zooarchaeology and taphonomy}

The vertebrate skeletal material recovered from LMD was identified by comparison with modern and archaeological reference specimens housed at The Australian National University (ANU) Osteology Collections in the Department of Archaeology and Natural History. Where possible, murid taxonomic identification was supplemented by aDNA results. Skeletal material was identified to element at the lowest taxonomic classification possible. Small lizards (Lacertilia) and snakes (Serpentes) could be identified only to order. Pacific fishbone studies usually only include family-level identifications of the five paired jaw bones due to difficulties reconciling morphological variability with high species diversity within tropical family groups, compounded by incomplete reference collections (Dye and Longenecker 2004), and this approach was followed here. The small amount of bird material was too fragmented for taxonomic determination, so this was recorded only by skeletal element.

The taphonomic history of bone deposition was investigated by measuring relative taxonomic abundance, taxonomic diversity, skeletal element representation, bone breakages and bone surface modifications. Since the sample represents a very limited temporal deposit, the assemblage was aggregated into one unit. Relative abundance was quantified by Number of Individual Specimens (NISP). Diversity was measured by simply counting the number of taxa present while the Shannon-Wiener diversity index (Keylock 2005) was calculated using PAST (Hammer et al. 2001) to measure the evenness of taxonomic representation. Evenness values close to 0 indicate faunal abundance is concentrated on a few taxa, whereas values close to 1 indicate a more even spread. This was applied to the lowest taxonomic level possible, with the highest taxonomic level excluded to reduce overlapping levels of diversity. In the case of murids these were aggregated regardless of taxonomy due to the uncertainty of identifications.

Skeletal elements were quantified by the Minimum Number of Elements (MNE) present. This was calculated by quantifying the most frequent side and portion of each skeletal element, recorded by distinctive morphological features, and fraction summation of long bone epiphyses and shafts. Murid skeletal element representation was calculated following Fernández et al. (2012) where the percentage of bone survivorship was estimated using the following formula: $\mathrm{MNEi} /(\mathrm{Ei} \times \mathrm{MNI})$ x 100 (where E = element, MNI = Minimum Number of Individuals). Murid bone breakage was investigated by calculating the proportions of complete, proximal, distal and shaft long bones, as well as the degree of skull breakage, following Andrews (1990).

Bone surface modifications recorded include coloration from a scale of $0-4$, with $0=$ no colour, 1 = light brown, 2 = dark brown, 3 = black, 4 = grey white. A select group of postcranial murid bones (humerus, radius, ulna, pelvis, femur, tibia) were observed under a high-powered microscope for signs of predator digestion on a scale of $0-4$, whereby $0=$ no digestion, $1=$ light digestion, 2 = moderate, 3 = heavy, and 4 = extreme as described by Andrews (1990). Tooth punctures from predators were also recorded.

\section{Pollen}

Sediment samples from each spit were thoroughly homogenised and $10 \mathrm{cc}$ subsamples taken for pollen processing, which followed standard $\mathrm{HCl}, \mathrm{KOH}$ and acetolysis methods (Faegri and Iversen 1989) and included addition of Lycopodium marker grains to calculate concentrations of pollen, spores and microscopic charcoal (Stockmarr 1971). Lithium polytungstate was used at a specific gravity of 2.0 to further concentrate pollen in the samples (Caffrey and Horn 2013). Pollen, spores and microscopic charcoal $(>10 \mu \mathrm{m})$ were counted at $400 \mathrm{x}$ magnification using a Zeiss Axiophot microscope and identifications made using the reference collection held at the Department of Archaeology and Natural History, ANU, and the Australian Pollen and Spore Atlas (APSA Members 2007). Pollen diagrams were produced using Tilia v. 2.0.33 (Grimm 2013). 


\section{Sediment analysis}

Particle size analysis of the sediment was carried out by laser diffraction using a Malvern Mastersizer 2000 with Hydro MU attachment housed at the Fenner School of Environment and Society, ANU. Pre-treatment of $2.5 \mathrm{cc}$ subsamples included $10 \% \mathrm{HCl}$ to remove carbonates, $30 \% \mathrm{H}_{2} \mathrm{O}_{2}$ to remove organic matter, addition of calgon to disperse aggregates and an additional 30 seconds of ultrasonic dispersal just prior to measurement. Organic matter content of the sediment was determined by loss on ignition (Dean 1974) using $2.5 \mathrm{cc}$ subsamples.

\section{Ancient DNA extraction, amplification and sequencing}

The DNA analysis included specimens recovered from the excavated deposits as well as several naturally deposited specimens. Two surface skeletons of Rattus rattus were collected during surveys. These remains were observed on the forest floor less than $2 \mathrm{~km}$ from LMD. Several additional faunal remains submitted for analysis were collected from the surface of Leang Warra, a small limestone cave situated on the eastern side of the island (Figure 14.1).

The samples were extracted, and PCR amplified in a specialised ancient DNA laboratory at the Australian Centre for Ancient DNA (ACAD) at the University of Adelaide, South Australia. These samples comprised incisor fragments. Preparation of samples for DNA extraction was carried out using a DNA extraction protocol based on a standard silica-based extraction (Brotherton et al. 2013). The incisors, ranging between $0.03 \mathrm{~g}$ to $0.07 \mathrm{~g}$, were each incubated for 1 hour under constant rotation at $37^{\circ} \mathrm{C}$ in $1.6 \mathrm{~mL}$ of $0.5 \mathrm{M}$ EDTA (Ethylenediaminetetraacetic acid), then replaced with fresh $0.5 \mathrm{M}$ EDTA and left to incubate for 24 hours. After decalcification, $40 \mu \mathrm{L}$ Proteinase $\mathrm{K}(20 \mathrm{mg} / \mathrm{mL})$ was added, and incubation continued for 2 hours at $55^{\circ} \mathrm{C}$. After lysis, the samples were centrifuged at $4,500 \mathrm{rpm}$ for 2 minutes to pellet undigested material. The supernatant was transferred to a $15 \mathrm{~mL}$ tube containing $100 \mu \mathrm{L}$ silica suspension and $3 \mathrm{~mL}$ of in-house binding buffer ( $4.0 \mathrm{~mL}$ QG buffer (Qiagen), $0.06 \mathrm{~mL}$ of $1 \mathrm{X}$ Triton, $20 \mathrm{mM} \mathrm{NaCl}$, $0.2 \mathrm{M}$ acetic acid (all Sigma-Aldrich)) and left to bind to silica for 1 hour at room temperature under slow and constant rotation. The samples were centrifuged for 3 minutes at 4,500 rpm to pellet silica particles and the supernatant was poured off. The pellet was transferred to a $1.5 \mathrm{~mL}$ tube and washed three times by resuspension in $1 \mathrm{~mL} 80 \%$ ethanol, centrifuged for 1 minute at $14,000 \mathrm{rpm}$ and the supernatant removed. The pellet was left to dry for 30 minutes and subsequently re-suspended in $200 \mu \mathrm{L}$ of pre-warmed (to $50^{\circ} \mathrm{C}$ ) TE buffer $(10 \mathrm{mM}$ Tris, $1 \mathrm{mM}$ EDTA) and incubated for 10 minutes. After pelleting for 1 minute at 13,000 rpm, the supernatant was collected, aliquoted and stored at $-18^{\circ} \mathrm{C}$ until further use.

PCRs were done using primer sets that amplify two overlapping fragments and another short fragment of the mitochondrial cytochrome $b(c y t b)$ gene. The sequences of the primers are: A1872 (5'-CCCCATCCAACATCTCATCA3')/A1873 (5'-TACGTCTCGGCAGATGTG-3'), A838 (5'-TAACAGCATTCTCATCAGT-3')/A839 (5'-TCCAATGTTTCATGTTTC-3'), and A1936 (5'-GGTTATGTACTCCCATGAGG-3')/A1937 (5'-GTTGCTTTGTCTACTGAGAA-3'). PCR reactions ( $25 \mu \mathrm{L}$ final volume) contained a final concentration of $1 \times$ HiFi PCR buffer (Invitrogen), $200 \mu \mathrm{M}$ each dNTP, 3 mM MgSO ${ }_{4}, 1 \mathrm{mg} . \mathrm{mL}-1$ Rabbit Serum Albumin (Sigma), $200 \mu \mathrm{M}$ of each primer and 1 Unit of Platinum TaqHiFi DNA polymerase (Invitrogen). Thermocycling included initial denaturation and enzyme activation at $94^{\circ} \mathrm{C}$ for 2 minutes, then 55 cycles of denaturing at $94^{\circ} \mathrm{C}$ for 30 seconds, primer annealing at $55^{\circ} \mathrm{C}$ for 30 seconds and extension at $68^{\circ} \mathrm{C}$ for 30 seconds, and a final extension $68^{\circ} \mathrm{C}$ for 10 minutes. Amplifications of extractions and PCR blank controls were also performed in all experiments to monitor for contamination. Amplicons were separated by electrophoresis on a 2.5\% agarose gel. Confirmatory re-amplification and re-sequencing was also performed for each PCR product for each specimen. PCR clean-up, Sanger sequencing and capillary electrophoresis were conducted at the Australian Genome Research Facility Ltd (Australia). 
The forward and reverse sequence chromatograms were assembled, visually inspected and edited manually using Geneious v.7.1.2 (Biomatters) to obtain a consensus sequence. The newly generated sequences were aligned with published Rattus rattus Complex sequences of known lineage affinity (from Aplin et al. 2011) using the Muscle alignment algorithm (Edgar 2004) and refined by eye to form a 367 bp alignment.

To ascertain the lineage identity of the Talaud Rattus specimens, and to demonstrate their evolutionary relationships with other rat sequences in Southeast Asia, we generated a haplotype network using Haplotype Viewer (www.cibiv.at/-greg/haploviewer). The input NeighbourJoining tree for the program was generated using the Juke-Cantor model of nucleotide substitution in Genius v.7.1.2 (Biomatters).

\section{Results}

\section{Archaeological excavation and dating}

The stratigraphy at LMD was as follows (Figure 14.2): Layer $1(0-20 \mathrm{~cm}$ uD (under Datum), 10YR 5/5) was found only in the northern part of 100/102 and consisted of light yellow-brown, very loose sandy silt. There was significant bioturbation by an earth wasp nest with particularly loose soil in the top $5 \mathrm{~cm}$. Layer $2(-10-25 \mathrm{~cm} \mathrm{uD}, 10 \mathrm{YR} 5 / 4)$ comprised a loose sandy silt, yellow-brown, slightly darker and slightly more compacted layer than Layer 1 . Frequent shell fragments and fine charcoal particles, some ceramics and stone artefacts were found. This was the main cultural layer at the site. Roots were observed frequently in the southern section of the square. Layer $3 \mathrm{a}(-25-\sim 60 \mathrm{~cm}$ uD, 10YR 5/5) comprised a compacted sandy silt with frequent clay concretions and tree roots. Only a few charcoal fragments and rare shell fragments were detected. No cultural artefacts were found in this layer. In the eastern section (square 100/102) bioturbation from an earth wasp nest was recorded up to $25 \mathrm{~cm}$ uD. Layer $3 \mathrm{~b}(-60-\sim 85-$ $100 \mathrm{~cm} \mathrm{uD}, 10 \mathrm{YR} 5 / 6$ ) was similar in structure and texture to Layer 3a, but more yellowish. It was slightly more compacted and sloping downward to the back of the shelter. No cultural artefacts were found in this layer. Layer $4(-85-140 \mathrm{~cm} \mathrm{uD}$, Munsell GLEY 5/10Y) comprised very compacted clay concretions in a silt-clay matrix with frequent limestone gravel. The deposit was increasingly gravelly to the base of the excavation. No cultural material was found in this layer and excavation was discontinued at this point, although sediment continues to an unknown depth.

Animal burrows at the back of the shelter were detected, which displaced fine material from lower deposits. While it is unclear whether cultural layers were disturbed, no artefacts were detected in this sediment. Stronger sloping deposits at the back of the shelter derived from the recent animal burrows. The sediment comprised predominantly silt and fine sand, and contained a low amount of organic matter (8.4-13.5\%), with frequent tree roots. Also on the southern side, there was significant rock fall, which appeared to be relatively recent. The excavation uncovered only a small archaeological assemblage comprising several stone artefacts and pottery fragments. The artefacts were archived at the Manado Archaeology Office and the technological analysis is pending. Due to the excavation methodology, a significant microfaunal assemblage was recovered (see below). A maximum age of 340 cal BP using OxCal 4.2 (ANU 37037, 225 \pm 25 , on kenari seed (Canarium sp.)) was determined for the cultural layer (Layer 2 in square 100/102). In square 100/101, a charred kenari nut husk from Spit 10 at the base of Layer 3 gave a modern age (ANU 37036, modern age, on charred kenari nut). On the basis of the radiocarbon dates, significant disturbance of the site is considered highly likely. 

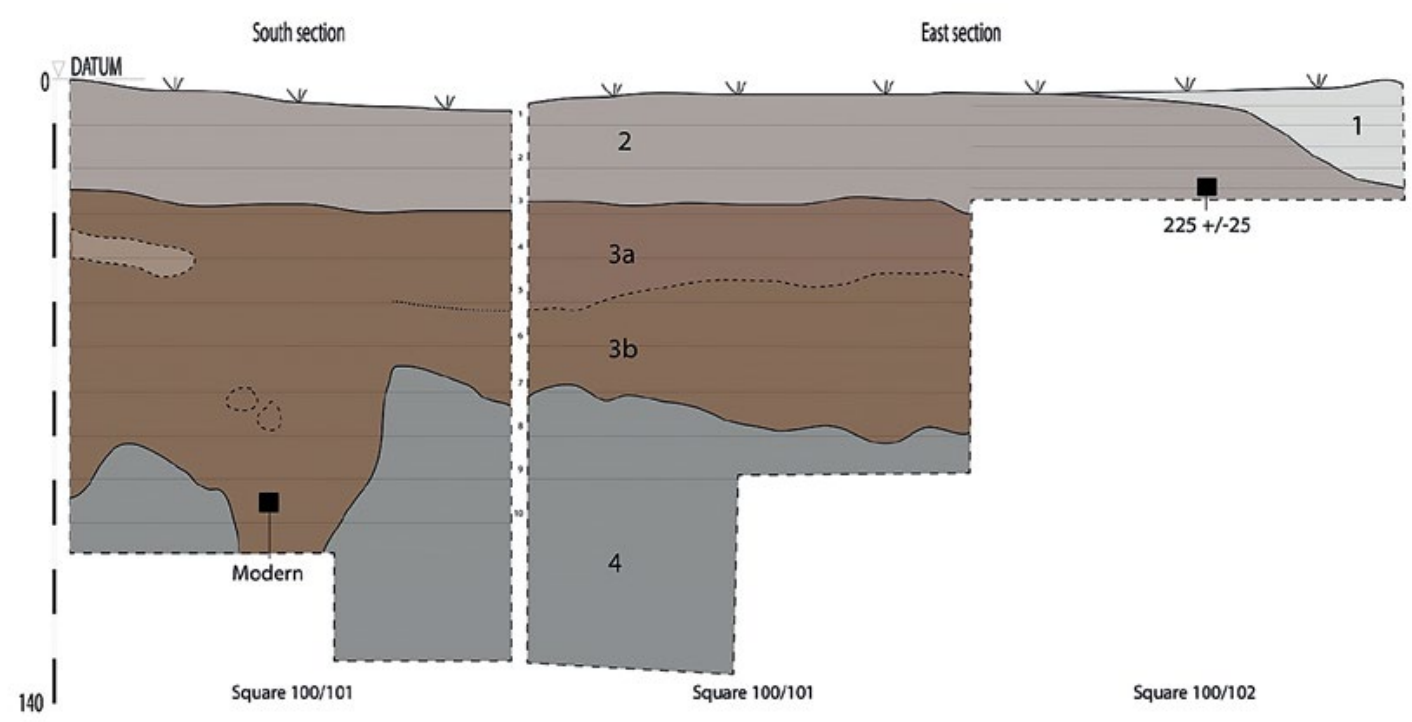

Figure 14.2: Stratigraphy of Leang Mande'et showing the location of the two dates recovered (black squares). Layers are indicated by numbers on the section; spits are indicated by horizontal lines within the sections and numbers listed between the south and east profiles.

Source: Section prepared by Julien Louys.

\section{Zooarchaeology and taphonomy}

A total of 784 vertebrate remains were recovered, with most of these concentrated in Spits 1 and 2, and as deep as Spit 6. At least 16 distinct taxa were recorded. These include five mammal species with four small murids (two Melomys spp., R. rattus, R. exulans), pig (Sus cf. scrofa), human (Homo sapiens) and an unidentified bat (Chiroptera). Six distinct fish families were identified, including triggerfishes (Balistidae), surgeonfishes, tangs and unicornfishes (Acanthuridae), snappers (Lutjanidae), sea basses and groupers (Serranidae), parrotfishes (Scaridae), and probably shark catfishes (cf. Pangasiidae). At least two reptile taxa, snakes (Serpentes) and small lizards (Lacertilia), and one bird taxon were present.

Small murids dominated the assemblage by NISP (56.1\%), with the remains of two native species of Melomys (M. talaudium and M. caurinus) outnumbering the remains of the two commensal Rattus species ( $R$. rattus and $R$. exulans) (Table 14.1). Other mammals present include pig (1.3\%), human $(0.6 \%)$ and bat $(0.1 \%)$. Fish bones were present in significant numbers $(18.9 \%)$, with much smaller proportions of reptiles $(4.1 \%)$ and birds (1.4\%). These results are reflected in a skewed Shannon-Wiener diversity index (0.59) towards small murids relative to fish and small reptiles, with an equitability J value of 0.23 (Taxa $=13$; Muridae, Sus, Chiroptera, Homo sapiens, Balistidae, Acanthuridae, Lutjanidae, Serranidae, Scaridae, cf. Pangasiidae, Aves, Lacertilia, Serpentes). 
Table 14.1: Number of Individual Specimens (NISP) for each spit from Leang Mande'et.

\begin{tabular}{|c|c|c|c|c|c|c|c|}
\hline Spit & 1 & 2 & 3 & 4 & 5 & 6 & Total \\
\hline Mammalia & NISP & NISP & NISP & NISP & NISP & NISP & NISP \\
\hline Muridae & 190 & 93 & 25 & 1 & 6 & 11 & 326 \\
\hline Melomys sp. & 41 & 8 & 1 & 0 & 0 & 1 & 51 \\
\hline cf. Melomys sp. & 2 & 4 & 0 & 0 & 0 & 0 & 6 \\
\hline Rattus rattus & 13 & 5 & 2 & 0 & 0 & 1 & 21 \\
\hline Rattus cf. rattus & 11 & 6 & 0 & 1 & 1 & 0 & 19 \\
\hline Rattus exulans & 2 & 0 & 0 & 0 & 0 & 0 & 2 \\
\hline Rattus cf. exulans & 2 & 1 & 0 & 0 & 0 & 0 & 3 \\
\hline Rattus sp. & 2 & 0 & 0 & 0 & 0 & 0 & 2 \\
\hline cf. Rattus sp. & 0 & 1 & 0 & 0 & 0 & 0 & 1 \\
\hline Muridae gen. et sp. Indet. & 3 & 6 & 0 & 0 & 0 & 0 & 9 \\
\hline Sus cf. scrofa & 2 & 3 & 4 & 0 & 0 & 1 & 10 \\
\hline Chiroptera & 0 & 1 & 0 & 0 & 0 & 0 & 1 \\
\hline Homo sapiens & 1 & 1 & 0 & 2 & 0 & 0 & 4 \\
\hline cf. Homo sapiens & 0 & 1 & 0 & 0 & 0 & 0 & 1 \\
\hline medium mammal & 5 & 14 & 13 & 7 & 0 & 0 & 39 \\
\hline \multicolumn{8}{|l|}{ Osteichthyes } \\
\hline Unidentified & 38 & 35 & 31 & 12 & 11 & 6 & 133 \\
\hline Balistidae & 0 & 1 & 1 & 2 & 1 & 1 & 6 \\
\hline Acanthuridae & 0 & 1 & 0 & 0 & 0 & 0 & 1 \\
\hline Lutjanidae & 0 & 1 & 0 & 0 & 0 & 0 & 1 \\
\hline Serranidae & 3 & 1 & 0 & 0 & 0 & 0 & 4 \\
\hline Scaridae & 2 & 0 & 0 & 0 & 0 & 0 & 2 \\
\hline cfPangasiidae & 0 & 0 & 0 & 0 & 0 & 1 & 1 \\
\hline \multicolumn{8}{|l|}{ Aves } \\
\hline Unidentified Aves & 3 & 5 & 1 & 0 & 0 & 0 & 9 \\
\hline cf. Aves & 2 & 0 & 0 & 0 & 0 & 0 & 2 \\
\hline \multicolumn{8}{|l|}{ Reptilia } \\
\hline Lacertilia & 3 & 6 & 3 & 0 & 0 & 0 & 12 \\
\hline Serpentes & 0 & 1 & 0 & 2 & 1 & 0 & 4 \\
\hline Unidentified reptile & 3 & 5 & 2 & 1 & 0 & 1 & 12 \\
\hline cf. Reptile & 1 & 2 & 1 & 0 & 0 & 0 & 4 \\
\hline Unidentified Vertebrate & 33 & 24 & 17 & 9 & 1 & 14 & 98 \\
\hline Total & 362 & 226 & 101 & 37 & 21 & 37 & 784 \\
\hline
\end{tabular}

Source: Stuart Hawkins' laboratory data.

The murids and small lizards were clearly deposited naturally as signs of non-human predation were prevalent amongst the terrestrial vertebrate specimens. Small puncture marks on murid lower limb bones (femora and tibiae) and caudal vertebra were frequently observed. In addition, high rates of moderate to extreme digestion patterns (Table 14.2) were noted on many of the murid and lizard bones, indicating predation by a raptor or possibly a larger varanid. The amount of digestion is far too high for a Barn owl (Tyto alba), which are often responsible for the deposition of small mammals in caves worldwide, and another owl species with a more powerful digestive tract may be responsible (see Andrews 1990). This indicates the site was not occupied permanently and saw periods of short cultural use, followed by periods of abandonment, as it is unlikely that avian or large lizard predators would cohabitate so closely to permanent human occupation. Skeletal element survivorship (Table 14.3) and bone breakage (Table 14.4) data 
indicate high loss of many skeletal elements and significant bone breakages, more so than that recorded for typical avian predation (Andrews 1990). Since recovery was fairly complete given the use of fine-meshed sieves, this was probably due to trampling and other site disturbances occurring during short periods of human occupation. Small numbers of murid bones appeared black or grey/blue/white, and this was likely due to burning (see Nicholson 1993). This most likely occurred as incidental burning in hearth fires of microfaunal remains already present within the deposit.

Table 14.2: Extent of digestion on murid postcranial elements.

\begin{tabular}{|c|c|c|c|c|c|c|c|c|c|c|c|}
\hline \multirow[b]{2}{*}{ Element } & \multicolumn{2}{|c|}{ Absent } & \multicolumn{2}{|c|}{ Light } & \multicolumn{2}{|c|}{ Moderate } & \multicolumn{2}{|c|}{ Heavy } & \multicolumn{2}{|c|}{ Extreme } & \multirow{2}{*}{ Total NISP } \\
\hline & $\mathrm{N}$ & $\%$ & $\mathrm{~N}$ & $\%$ & $\mathrm{~N}$ & $\%$ & $\mathrm{~N}$ & $\%$ & $\mathrm{~N}$ & $\%$ & \\
\hline Humerus & 8 & 61.54 & 3 & 23.08 & 1 & 7.69 & 1 & 7.69 & 0 & 0 & 13 \\
\hline Ulna & 3 & 30 & 2 & 20 & 1 & 10 & 3 & 30 & 1 & 10 & 10 \\
\hline Radius & 7 & 77.78 & 1 & 11.11 & 0 & 0 & 1 & 11.11 & 0 & 0 & 9 \\
\hline Pelvis & 5 & 50 & 0 & 0 & 2 & 20 & 1 & 10 & 2 & 20 & 10 \\
\hline Femur & 14 & 45.16 & 5 & 16.13 & 5 & 16.13 & 5 & 16.13 & 2 & 6.45 & 31 \\
\hline Tibia & 15 & 53.57 & 7 & 25 & 4 & 14.29 & 1 & 3.57 & 1 & 3.57 & 28 \\
\hline
\end{tabular}

Source: Stuart Hawkins' laboratory data.

Table 14.3: Murid element survivorship.

\begin{tabular}{|l|r|}
\hline Element & \%MNE survivorship \\
\hline Maxilla & 38.1 \\
\hline Mandible & 35.71 \\
\hline Incisors & 80.95 \\
\hline Atlas & 14.29 \\
\hline Axis & 19.05 \\
\hline Cervical & 3.81 \\
\hline Thoracic & 1.1 \\
\hline Rib & 1.28 \\
\hline Lumbar & 3.97 \\
\hline Sacrum & 4.76 \\
\hline Caudal & 6.12 \\
\hline Scapula & 11.91 \\
\hline Humerus & 19.05 \\
\hline Ulna & 19.05 \\
\hline Radius & 21.43 \\
\hline Pelvis & 16.67 \\
\hline Femur & 35.71 \\
\hline Tibia & 30.95 \\
\hline Metapodial & 12.17 \\
\hline Calcaneus & 21.43 \\
\hline Astragalus & 2.38 \\
\hline Phalange & 3.04 \\
\hline
\end{tabular}

Source: Stuart Hawkins' laboratory data. 
Table 14.4: Murid skeletal element breakages.

\begin{tabular}{|c|c|c|}
\hline Skeletal element & $\mathrm{N}$ & $\%$ \\
\hline \multicolumn{3}{|l|}{ Skull } \\
\hline Complete & 0 & 0 \\
\hline Maxillary with zygomatic & 2 & 15.39 \\
\hline Maxillary without zygomatic & 11 & 84.62 \\
\hline \multicolumn{3}{|l|}{ Mandible } \\
\hline Complete & 0 & 0 \\
\hline Ascendingramus broken & 3 & 13.64 \\
\hline Without ascending ramus & 5 & 22.73 \\
\hline Without ascending ramus, inferior edge broken & 14 & 63.64 \\
\hline \multicolumn{3}{|l|}{ Postcrania } \\
\hline \multicolumn{3}{|l|}{ Humerus } \\
\hline Complete & 1 & 8.33 \\
\hline Proximal & 1 & 8.33 \\
\hline Shaft & 5 & 41.67 \\
\hline Distal & 5 & 41.67 \\
\hline \multicolumn{3}{|l|}{ Ulna } \\
\hline Complete & 0 & 0 \\
\hline Proximal & 5 & 41.67 \\
\hline Shaft & 5 & 41.67 \\
\hline Distal & 2 & 16.67 \\
\hline \multicolumn{3}{|l|}{ Femur } \\
\hline Complete & 0 & 0 \\
\hline Proximal & 14 & 42.42 \\
\hline Shaft & 7 & 21.21 \\
\hline Distal & 12 & 36.36 \\
\hline \multicolumn{3}{|l|}{ Tibia } \\
\hline Complete & 3 & 9.68 \\
\hline Proximal & 6 & 19.35 \\
\hline Shaft & 6 & 19.35 \\
\hline Distal & 16 & 51.61 \\
\hline
\end{tabular}

Source: Stuart Hawkins' laboratory data.

\section{Pollen}

No pollen, spores or microscopic charcoal were observed in Spit 10, and only very low concentrations were present in Spits 6-9. With the exception of Spit 9, the total terrestrial pollen count was very low for these spits and the data presented as presence/absence of taxa only (Figure 14.3). There was a notable lack of observed forest taxa with palms, Euphorbiaceae and herbs predominating. Spit 9 contained almost exclusively Cocos nucifera pollen. Pollen concentrations improved in Spits 4-5 and were highest in Spits 1-3. After Spit 4, there was a reduction in other palm taxa and Euphorbiaceae and an increase in the diversity of identified forest taxa and Cocos nucifera. Only a small amount of fern spores was observed and microscopic charcoal particle concentrations were highest in Spits 1-4. 


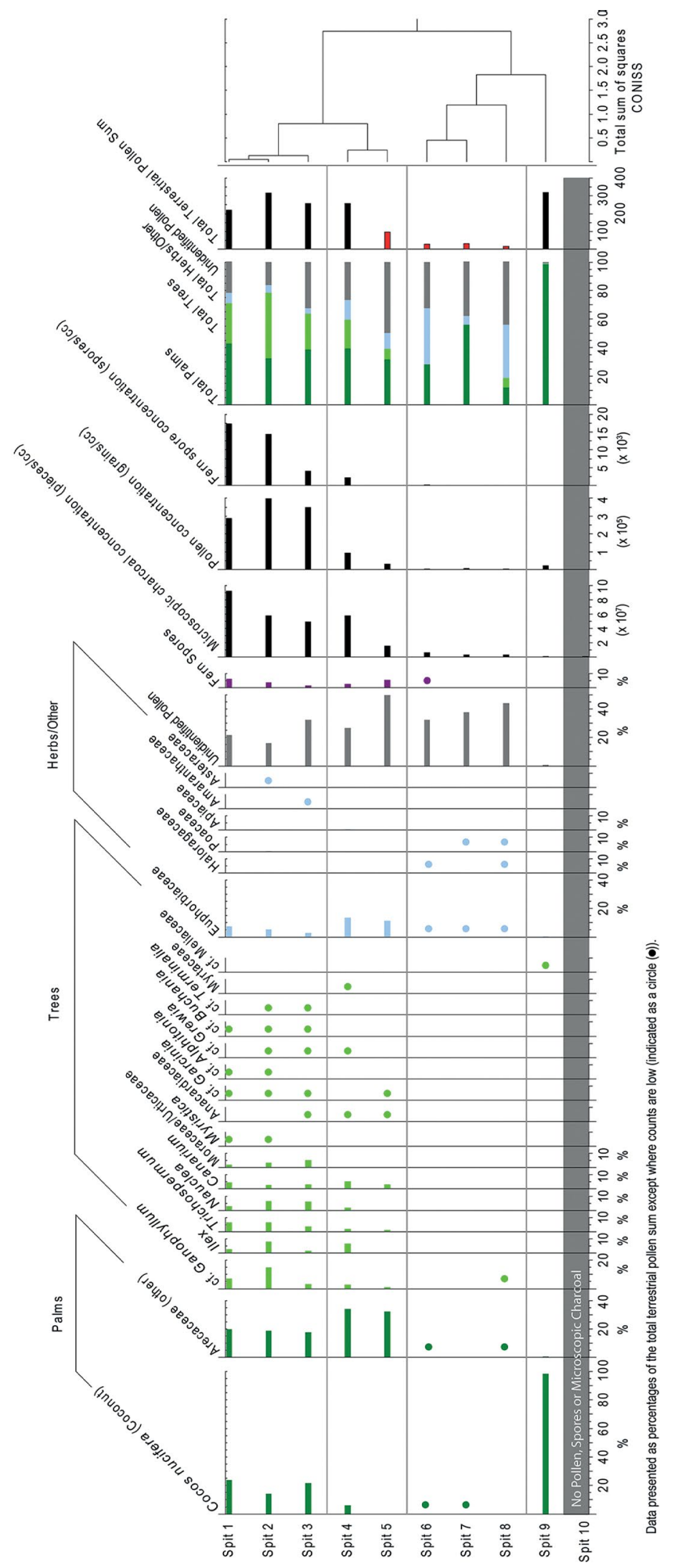

Figure 14.3: Summary diagram of pollen recovered from each spit of Leang Mande'et. Source: Felicitas Hopf's laboratory data. 


\section{Taxonomy and aDNA}

Three $c y t b$ haplotypes were found in the $R$. rattus samples from Talaud, all belonging to $\operatorname{RrC}$ lineage IV (Figure 14.4; Appendix A). The Talaud haplotypes formed a discrete sub-lineage that is not known from elsewhere in the region and adds to the known diversity of $\mathrm{RrC}$ lineage IV in ISEA. The central haplotype of the Talaud sub-lineage differed by two substitutions from a haplotype that is common in both Indonesia and the Philippines. A maximum of four substitutions were observed between the two most divergent of the Talaud haplotypes. The basal position of the Talaud samples within lineage IV, relative to the other lineages of the $\mathrm{RrC}$ was a product of the relatively short (356 bp) segment of cytb used in computation of this network. Analysis of longer segments of cytb placed the common Indonesian/Philippine network in a peripheral position relative to the central diversity observed among samples from Indochinese localities (Aplin et al. 2011).

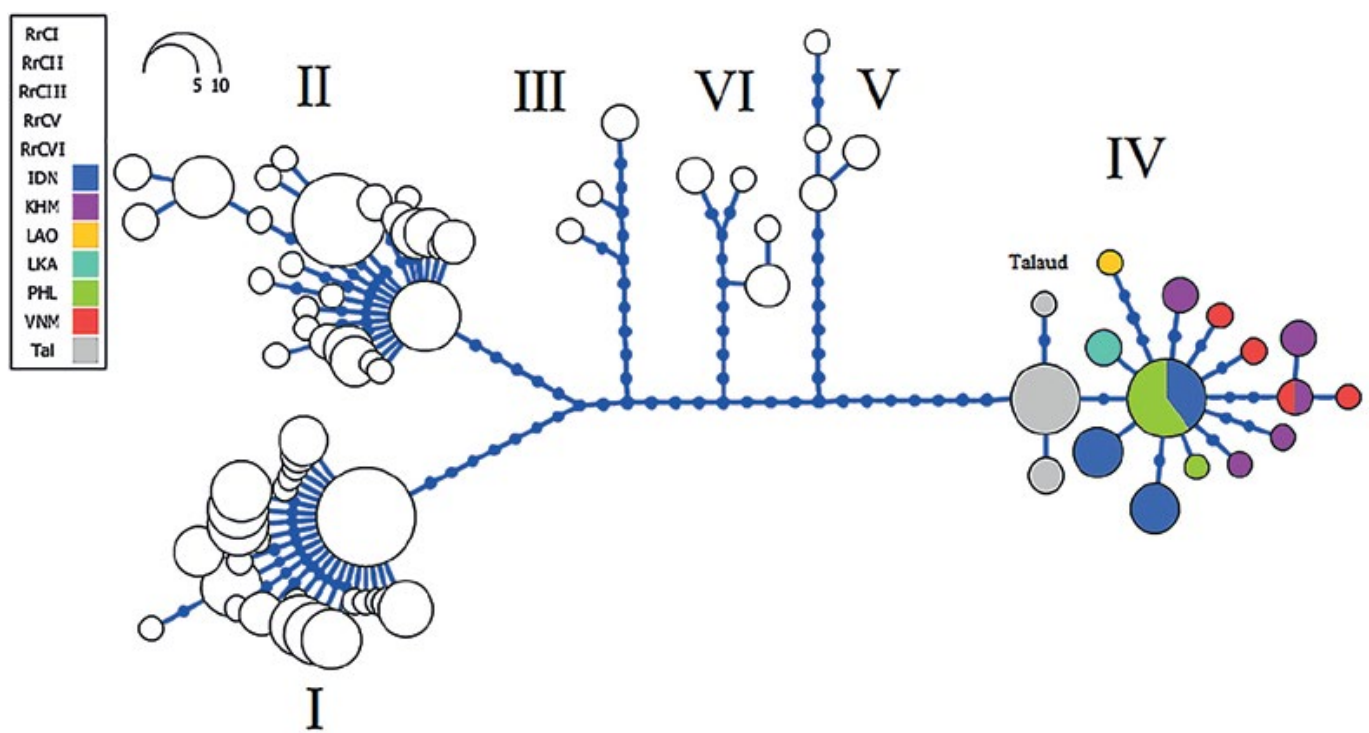

Figure 14.4: Haplotype network of cytochrome $b$ dataset comprising 367 bp across Rattus rattus complex lineages. Colours of RrC lineage IV haplotypes are blue (IDN-Indonesia), purple (KHM-Cambodia), orange (LA0-Laos), light blue (LKA-Sri Lanka), green (PHL-Philippines), red (VNM-Vietnam), grey (TalTalaud). Blue dots represent the number of mutations leading to a haplotype.

Source: Michael Herrera and Stephen Donnellan's laboratory data.

\section{Discussion}

The site shows significant disturbance, with a modern date produced from Spit 9, and bioturbation observed during excavation. Despite the disturbed nature of the sediments, it's evident that during the short periods when humans recently occupied LMD, their subsistence practices were focused on agriculture of the surrounding hill slopes. Active gardens were observed during fieldwork, with lowland tropical moist forest dominating local conditions near the site, interspersed gardens on the hillslope leading up to LMD and coconut plantations at sea level. In the deposit, coconut (Cocos nucifera) dominates Spit 9, although it is present in most other spits in lower amounts other than Spits 5 and 8. While long distance transport of coconut pollen can't be ruled out (Maloney 1993), it is thought to be predominantly dispersed by insects (Anderson et al. 1988) and, as a result, an indicator of the local presence of coconut palms. Wind dispersal of coconut pollen through forests is limited to about $180 \mathrm{~m}$ from a coconut plantation 
(Manthriratna 1965). Coconut palms are not found inland unless planted (Harries 1978), thus the significant proportions of coconut pollen in the LMD record suggest coconut trees were agricultural in nature. Interestingly, coconuts may not have been widespread on Talaud during the pre-colonial period. Historical records indicate that:

Until about 1885 there were said to be 'almost no coconut trees' on the Talaud Islands. Possibly this was because the Sangirese kingdoms to which they were subject had succeeded up to that point in discouraging the export of oil or copra. Thereafter the crop spread rapidly, and Talaud participated in the copra boom. In 1920, nevertheless, it was still 'only the lower parts' of the larger islands which were occupied by coconut gardens, while timber, including valuable ebony, remained plentiful elsewhere (Henley 2005:512).

Thus, the pollen data suggests that deposition of the site was predominately post-colonial. It further suggests that gardening activities at LMD focused, at least in part, on coconut, a low-maintenance crop. During irregular gardening activities, fish were evidently brought to the rockshelter for consumption. These were mostly marine herbivorous and carnivorous reef fishes that could have been caught by people using nets, spears, traps and baited hooks and lines (e.g. Ono 2010) from the adjacent bay. However, the tentative shark catfish bone identification indicates possible utilisation of brackish freshwater environments, such as nearby rivers and streams or the nearby river mouth. Adult pig remains were present from Spit 1 to Spit 6 and include teeth, phalanges, sesamoids and vertebra elements. The mandibular canine showed signs of percussion and may indicate removal of these for ceremonial items. This suggests pigs were also brought to the site and could indicate that small ceremonial feasts were conducted at the shelter. The human teeth recovered may be intrusive from a potential burial adjacent to the excavation pits or lost by individuals at the site during the course of their lifetime.

All the small murid remains recovered from LMD were deposited evidently by non-human predators. The dominance of the endemic Melomys species over the introduced commensal species of Rattus is noteworthy. These species are known from few modern specimens, and their current status and ecology are poorly documented (Corbet and Hill 1992; Flannery 1995; Riley 2002). Melomys caurinus is thought to be terrestrial on account of its relatively short tail, and $M$. talaudium to be arboreal. Both are ranked Endangered in the IUCN Red List, although Riley (2002) considered them to be present in both primary and secondary forests, and to be secure (Riley 2002). We recovered the remains of a minimum of 17 individuals of Melomys spp. (NISP=51), including representatives of both endemic species. Some of these are currently being sampled for DNA, and the results will be reported elsewhere. The abundance of the Melomys species in the deposit suggests that they were not displaced as a result of the introduction of the commensal rodents ( $R$. rattus and $R$. exulans) and were able to thrive in a landscape that has been anthropogenically disturbed and irregularly used for gardening for at least several hundred years. Given this apparent resilience, it would seem likely that they may be under less severe threat than suggested by current IUCN ranking.

The genetic data from the archaeological specimens provides the first evidence for the lineage identity of $R$. rattus on the Talaud Islands. The fact that the samples produced a total of three closely related haplotypes of $\mathrm{RrC}$ lineage IV is significant for several reasons. In the first place, the recovery of a unique sub-lineage thus far known only from the Talaud Islands points to a potentially early introduction followed by the in situ production of genetic diversity through local mutation within the Talaud Archipelago. However, the alternative possibility that the diversity was created elsewhere and imported through separate dispersal events cannot be discounted altogether, even though it seems unlikely. The notion that lineage IV R. rattus reached the Talaud Islands at a relatively early date can be tested by the discovery of new sites that extend the record of murids back even a few thousand years. 
The second point of great interest is the occurrence of lineage IV rather than lineage II in the Talaud Islands. At face value, this appears to favour a southern route of colonisation into the Talaud Archipelago, presumably from somewhere in Wallacea and most likely from northern Sulawesi. However, it must be noted that the widespread haplotype that appears to be the ancestral haplotype for the Talaud sub-lineage is present also in the Philippines-strictly speaking, the Talaud population might have come from either direction. However, given that Indonesia was clearly occupied by lineage IV from early times (Aplin et al. 2011), to postulate that they came to the Talaud Islands from the north would require an initial dispersal from Wallacea to the Philippines followed by a back-dispersal to the Talaud Islands. Until such time as there is independent evidence to support this more complex history, we will assume that the simpler version is correct-i.e. that the Talaud Islands population was introduced in ancient times from the south. To pinpoint the place of origin more closely, further sampling of $\mathrm{RrC}$ lineage IV Black rats is needed for Sundaland, especially Borneo, as well as the various Moluccan island groups, and Sulawesi.

A southern rather than northern origin of the Talaud Black rat population appears to be contrary to more general thinking concerning the pattern of dispersal of agricultural practices (and presumably their associated commensal pest rodents) through this region. The Talaud Archipelago has a relatively ancient record of occupation, represented by the Pleistocene-aged site of Leang Sarru. This site preserves evidence of episodic occupation during the Pleistocene and early Holocene: between c. 35 and $32 \mathrm{cal} \mathrm{BP}$, between c. 21 and $18 \mathrm{cal} \mathrm{BP}$, and again between 10 and 8 cal BP (Ono et al. 2009; Tanudirjo 2001, 2005), but none of these early phases provide any clue as to the direction of human dispersals. By contrast, the Neolithic-aged site of Leang Tuwo Mane'e, situated on Karakelang Island, has resulted in the island group featuring heavily in models describing the initial dispersal routes of Neolithic innovations, exemplified by the Blust-Bellwood model of Austronesian expansion (Bellwood 2007). This model is predicated on the similarities observed between the sub-grouping structure of the Austronesian language family tree and the patterns of distributions of cultural materials such as stone adzes, red-slipped pottery, rock art, domesticated animals and certain kinds of shell ornament. In this model, Taiwan is regarded as the point of origin for Proto-Austronesian peoples, from which agricultural groups migrated rapidly after about 4,000 cal BP into the Philippines, then the Moluccas, Sulawesi, Micronesia and further into the Western Pacific. While this longstanding colonisation model is accepted by many researchers working in Southeast Asia and Oceania, a number of recent discoveries and new analyses (Barker and Richards 2013), including those regarding the translocation of domesticated animals (Piper 2017) and the distribution and origin of the 'Austronesian Painting Tradition' (O'Connor et al. 2015), suggest that the origins and dispersal history of the Austronesians may not be as clear-cut as the Blust-Bellwood model predicts.

If commensal rats moved around as part of a complete 'package' of agricultural innovations and associated problems, the Blust-Bellwood model would predict the occurrence of lineage II of the $\mathrm{RrC}$ on the Talaud Islands, as there would seem to be quite strong genetic evidence to postulate an early dispersal of one or more sub-lineages of lineage II out of Taiwan and into areas subsequently occupied by Austronesian speaking peoples (Aplin et al. 2011). The lack of $\mathrm{RrC}$ lineage II rats in the LMD assemblage thus generates a number of competing scenarios that are testable by recovery of further data. Foremost is the possibility that the earliest dispersal of agricultural peoples and/or practices was not accompanied by commensal rodents, but that these were introduced subsequently and potentially from a different direction to the original dispersal of agriculture. Failure to find commensal rodent remains in the earliest agricultural sites on the Talaud Islands would support this notion, especially if the sites did yield remains of the native murids Melomys spp. Another possibility is that an initial population of lineage II 
Black rats, introduced from the north, was later replaced by a secondary southern immigrant of lineage IV, or if not replaced then at least heavily introgressed by lineage IV mtDNA. This notion is testable through the discovery, DNA testing and direct dating of $R$. rattus remains from earlier archaeological sites.

Other groups of organisms might also provide independent clues concerning the ancient human and biotic dispersal routes. The Sangihe-Talaud Archipelago complex represents a natural stepping stone for an initial Austronesian expansion south from Taiwan, into the Philippines and thence into the Moluccas and Sulawesi. However, biogeographical data from other organisms, specifically the herpetofauna, strongly suggest that the Talaud Islands themselves may never have served as a natural waypoint between the Philippines and northern Sulawesi, with a route through the Sangihe Islands considered more likely (Koch et al. 2009). The herpetofauna instead hint at strong biogeographical connections between the Talaud Archipelago and the Moluccas, with only weaker links evident between the Talaud Islands and the Philippines and Sulawesi (Koch et al. 2009). Meanwhile, the common presence of several mammalian taxa on the Philippines, Sangihe and northern Sulawesi but not Talaud, such as stegodons, squirrels and, for the latter two islands, tarsiers, suggests strong biogeographic connections between these island groups. While all such dispersals are likely to have been stochastic and considerably more ancient than the Austronesian expansion, the biogeographical record, underpinned by movement dictated by oceanic currents, nevertheless suggests that a route through Sangihe might have been more likely for seafaring Neolithic peoples. Unfortunately, and despite surveys over considerable parts of the island, neither natural nor archaeological deposits have been identified on Sangihe.

\section{Conclusions}

The significant Neolithic human migration that occurred throughout ISEA, suggested by the occurrence of red-slipped ceramics, ground stone tools, a rock art tradition focusing on the depiction of boats and anthropogenic figures on cliff faces, and remains of cereal plants and domesticated animals is thought to be strongly linked to the spread of Austronesian languages from Taiwan. Attempts to trace this Austronesian movement have traditionally relied on the recovery of these types of evidence from the archaeological record. The absence of such evidence makes it difficult to accurately trace directions and timings of movements of Neolithic peoples. The Talaud Islands had been no exception to this, and little evidence of the direction of origin of Austronesians exists in the archipelago. However, the recovery of significant numbers of DNAproducing rodents from the Talaud Islands allows us to make inferences on the origins and number of independent colonisation events of the islands by people who brought with them rats (i.e. probably agriculturalists). All Black rats recovered from Karakelang Island belong to $\mathrm{RrC}$ lineage IV, a group with origins in southern Indochina with subsequent dispersals, coincident with the spread of human agricultural communities, into eastern Indonesia and the Philippines. Significantly, our analyses failed to recover any $\mathrm{RrC}$ lineage II rats, which are characteristic of similar movements between northern Indochina, South Asia and Taiwan. Furthermore, our genetic data strongly suggests that there was only one dispersal event of Black rats into the Talaud Islands, and that this represents an early migration for the group. While Talaud's rat record does not provide clues as to the identity of the island's first agriculturalists, it does suggest that they either originated from the south; or that, once established in Talaud, the Neolithic communities in Talaud opened up significant trade networks to the south and, in the process, acquired a significant pest whilst helping to write genetic history. 


\section{Acknowledgements}

This research was funded through an ARC Laureate Fellowship to Professor Sue O'Connor (FL120100156), a Discovery Project Award (DP140103650) to Stephen Donnellan, Ken Aplin and Phil Piper, and a Discovery Early Career Researcher Award (DECRA, DE130100046) to Christian Reepmeyer. We thank the staff from the Manado Archaeology Office, particularly Drs Bonny A. Tooy, S.S. Sriwigati and S. Si. Paulina E.H. Nugrahini, for their help organising the fieldwork, the Australian Centre for Ancient DNA, University of Adelaide, for facilities and technical support, and Vicki Thomson for designing the PCR primers for the DNA analysis.

\section{Author biographies}

Julien Louys Department of Archaeology and Natural History, School of Culture, History and Language, College of Asia and the Pacific, The Australian National University, Canberra, Australia

Michael Herrera School of Biological Sciences, the University of Adelaide, Adelaide, Australia

Stuart Hawkins Department of Archaeology and Natural History, School of Culture, History and Language, College of Asia and the Pacific, The Australian National University, Canberra, Australia

Ken Aplin Department of Archaeology and Natural History, School of Culture, History and Language, College of Asia and the Pacific, The Australian National University, Canberra, Australia

Christian Reepmeyer Department of Archaeology and Natural History, School of Culture, History and Language, College of Asia and the Pacific, The Australian National University, Canberra, Australia; and College of Arts, Society and Education, Cairns Campus, James Cook University, Cairns, Australia

Felicitas Hopf Department of Archaeology and Natural History, School of Culture, History and Language, College of Asia and the Pacific, The Australian National University, Canberra, Australia; and ARC Centre of Excellence for Australian Biodiversity and Heritage, The Australian National University, Canberra, Australia

Stephen C. Donnellan South Australia Museum and School of Biological Sciences, University of Adelaide, Adelaide, Australia

Sue O'Connor Department of Archaeology and Natural History, School of Culture, History and Language, College of Asia and the Pacific, The Australian National University, Canberra, Australia; and ARC Centre of Excellence for Australian Biodiversity and Heritage, The Australian National University, Canberra, Australia

Daud A. Tanudirjo Department of Archaeology, Gadjah Mada University, Yogyakarta, Indonesia

\section{References}

Anderson, A.B., W.L. Overal and A. Henderson. 1988. Pollination ecology of a forest-dominant palm (Orbignya phalerata Mart.) in northern Brazil. Biotropica 20(3):192-205. doi.org/10.2307/2388234 (accessed 5 June 2018).

Andrews, P. 1990. Owls, Caves and Fossils: Predation, Preservation and Accumulation of Small Mammal Bones in Caves, with an Analysis of the Pleistocene Cave Faunas From Westbury-Sub-Mendip. Somerset: University of Chicago Press. 
Aplin, K.P., H. Suzuki, A.A. Chinen, R.T. Chesser, J. ten Have, S.C. Donnellan, J. Austin, A. Frost, J.P. Gonzalez, V. Herbreteau, F. Catzeflis, J. Soubrier, Y.-P. Fang, J. Robins, E. Matisoo-Smith, A.D.S. Bastos, I. Maryanto, M.H. Sinaga, C. Denys, R.A. Van Den Bussche, C. Conroy, K. Rowe and A. Cooper. 2011. Multiple geographic origins of commensalism and complex dispersal history of black rats. PLoS ONE 6(11):e26357. doi.org/10.1371/journal.pone.0026357 (accessed 5 June 2018).

APSA Members. 2007. The Australasian Pollen and Spore Atlas V1.0. The Australian National University. apsa.anu.edu.au/ (accessed 5 June 2018).

Barker, G. and M.B. Richards. 2013. Foraging-farming transitions in Island Southeast Asia. Journal of Archaeological Method and Theory 20(2):256-280. doi.org/10.1007/s10816-012-9150-7 (accessed 5 June 2018).

Bellwood, P. 2007. Prehistory of the Indo-Malaysian Archipelago. Revised edition. Canberra: ANU E Press, doi.org/10.26530/OAPEN_459472 (accessed 5 June 2018).

Bellwood, P. 2011. Holocene population history in the Pacific Region as a model for worldwide food producer dispersals. Current Anthropology 52(S4):S363-S378. doi.org/10.1086/658181 (accessed 5 June 2018).

Blust, R. 1995. The prehistory of the Austronesian-speaking peoples: A view from language. Journal of World Prehistory 9(4):453-510. doi.org/10.1007/BF02221119 (accessed 5 June 2018).

Brotherton, P., W. Haak, J. Templeton, G. Brandt, J. Soubrier, C.J. Adler, S.M. Richards, C. Der Sarkissian, R. Ganslmeier and S. Friederich. 2013. Neolithic mitochondrial haplogroup H genomes and the genetic origins of Europeans. Nature Communications 4(1764). doi.org/10.1038/ncomms2656 (accessed 5 June 2018).

Caffrey, M.A. and S.P. Horn. 2013. The use of lithium heteropolytungstate in the heavy liquid separation of samples which are sparse in pollen. Palynology 37(1):143-150. doi.org/10.1080/01916122.2012. 736417 (accessed 5 June 2018).

Corbet, G.B. and J.E. Hill. 1992. The Mammals of the Indomalayan Region: A Systematic Review. Oxford: Oxford University Press.

Dean, W.E. 1974. Determination of carbonate and organic matter in calcareous sediments and sedimentary rocks by loss on ignition; comparison with other methods. Journal of Sedimentary Research 44(1):242-248. doi.org/10.1306/74d729d2-2b21-11d7-8648000102c1865d (accessed 5 June 2018).

Dye, T. and K.R. Longenecker. 2004. Manual of Hawaiian Fish Remains Identification Based on the Skeletal Reference Collection of Alan C. Ziegler and including Otoliths. Hawai' $\mathrm{i}$ : Society for Hawaiian Archaeology (in English).

Edgar, R.C. 2004. MUSCLE: Multiple sequence alignment with high accuracy and high throughput. Nucleic Acids Research 32(5):1792-1797. doi.org/10.1093/nar/gkh340 (accessed 5 June 2018).

Fægri, K. and J. Iversen. 1989. Textbook of Pollen Analysis. Chichester: John Wiley and Sons.

Fernández, F.J., P. Teta, R. Barberena and U.F.J. Pardiñas. 2012. Small mammal remains from Cueva Huenul 1, northern Patagonia, Argentina: Taphonomy and paleoenvironments since the Late Pleistocene. Quaternary International 278:22-31. doi.org/10.1016/j.quaint.2012.01.005 (accessed 5 June 2018).

Flannery, T.F. 1995. Mammals of the South-West Pacific \& Moluccan Islands. Ithaca, N.Y.: Cornell University Press.

Grimm, E.C. 2013. Tilia v2.0.33. Springfield: Illinois State Museum.

Hammer, Ø., D.A.T. Harper and P.D. Ryan. 2001. PAST: Paleontological statistics software package for education and data analysis. Palaeontologia Electronica 4(1):1-9. 
Harries, H.C. 1978. The evolution, dissemination and classification of Cocos nucifera L. The Botanical Review 44(3):265-319. doi.org/10.1007/bf02957852 (accessed 5 June 2018).

Henley, D. 2005. Fertility, Food and Fever: Population, Economy and Environment in North and Central Sulawesi, 1600-1930. Leiden: KITLV Press.

Keylock, C.J. 2005. Simpson diversity and the Shannon-Wiener index as special cases of a generalized entropy. Oikos 109(1):203-207. doi: 10.1111/j.0030-1299.2005.13735.x (accessed 5 June 2018).

Koch, A., E. Arida, A. Riyanto and W. Böhme. 2009. Islands between the realms: A revised checklist of the herpetofauna of the Talaud Archipelago, Indonesia, with a discussion about its biogeographic affinities. Bonner Zoologische Beiträge 56(1/2):107-129.

Maloney, B.K. 1993. Palaeoecology and the origin of the coconut. GeoJournal 31(4):355-362.

Manthriratna, M. 1965. Coconut pollen. Ceylon Coconut Quarterly 16:102-110.

Matisoo-Smith, E. and J.H. Robins. 2004. Origins and dispersals of Pacific peoples: Evidence from mtDNA phylogenies of the Pacific rat. Proceedings of the National Academy of Sciences of the United States of America 101(24):9167-9172. doi.org/10.1073/pnas.0403120101 (accessed 5 June 2018).

Nicholson, R.A. 1993. A morphological investigation of burnt animal bone and an evaluation of its utility in archaeology. Journal of Archaeological Science 20(4):411-428. doi.org/10.1006/jasc.1993.1025 (accessed 5 June 2018).

O'Connor, S., J. Louys, S. Kealy and Mahirta. 2015. First record of painted rock art in Kupang, West Timor, Indonesia and the origins and distribution of the Austronesian Painting Tradition. Rock Art Research 32(2):193-201.

Ono, R. 2010. Ethno-archaeology and early Austronesian fishing strategies in near-shore environments. The Journal of the Polynesian Society 119(3):269-314.

Ono, R., S. Soegondho and M. Yoneda. 2009. Changing marine exploitation during Late Pleistocene in Northern Wallacea: Shell remains from Leang Sarru Rockshelter in Talaud Islands. Asian Perspectives 48(2):318-341. doi.org/10.1353/asi.2009.0002 (accessed 5 June 2018).

Pagès, M., Y. Chaval, V. Herbreteau, S. Waengsothorn, J.-F. Cosson, J.-P. Hugot, S. Morand and J. Michaux. 2010. Revisiting the taxonomy of the Rattini tribe: A phylogeny-based delimitation of species boundaries. BMC Evolutionary Biology 10(184):1-27. doi.org/10.1186/1471-2148-10-184 (accessed 5 June 2018).

Piper, P.J. 2017. The origins and arrival of the earliest domestic animals in Mainland and Island Southeast Asia: A developing story of complexity. In P.J. Piper, H. Matsumura and D. Bulbeck (eds), New Perspectives in Southeast Asian and Pacific Prehistory, pp. 251-274. Canberra: ANU Press. doi.org/ 10.22459/TA45.03.2017.15 (accessed 5 June 2018).

Riley, J. 2002. Mammals on the Sangihe and Talaud Islands, Indonesia, and the impact of hunting and habitat loss. Oryx 36(3):288-296. doi.org/10.1017/S0030605302000510 (accessed 5 June 2018).

Robins, J.H., P.A. McLenachan, M.J. Phillips, L. Craig, H.A. Ross and E. Matisoo-Smith. 2008. Dating of divergences within the Rattus genus phylogeny using whole mitochondrial genomes. Molecular Phylogenetics and Evolution 49(2):460-466. doi.org/10.1016/j.ympev.2008.08.001 (accessed 5 June 2018).

Spriggs, M. 2011. Archaeology and the Austronesian expansion: Where are we now? Antiquity 85(328):510 528. doi.org/10.1017/S0003598X00067910 (accessed 5 June 2018).

Stockmarr, J. 1971. Tablets with spores used in absolute pollen analysis. Pollen Spores 13:615-621. 
Tanudirjo, D.A. 2001. Islands in Between: Prehistory of the Northeastern Indonesian Archipelago. Unpublished PhD thesis, School of Archaeology and Anthropology, The Australian National University, Canberra.

Tanudirjo, D.A. 2005. Long-continuous or short-occasional occupation? The human use of Leang Sarru rockshelter in the Talaud Islands, northeastern Indonesia. Bulletin of The Indo-Pacific Prehistory Association 25(3):15-19.

Thomson, V., K.P. Aplin, A. Cooper, S. Hisheh, H. Suzuki, I. Maryanto, G. Yap and S.C. Donnellan. 2014. Molecular genetic evidence for the place of origin of the Pacific rat, Rattus exulans. PLoS ONE 9(3):e91356. doi.org/10.1371/journal.pone.0091356 (accessed 5 June 2018).

Yosida, T.H. 1980. Cytogenetics of the Black Rat: Karyotype Evolution and Species Differentiation. Tokyo: University of Tokyo Press.

\section{Appendix A}

The sequences of the Talaud haplotype 1,2, and 3. Sequence for the overlapping fragments 1 and 2 is situated between base positions 14,220 and 14,480 based on the Rattus novergicus whole mitochondrial genome sequence with GenBank accession number AJ428514. Fragment 3 is situated between positions 14,519 and 14,624 of the same sequence.

\section{Fragments 1 and 2}

\section{Talaud Haplotype 1}

TGATGAAATTTTGGCTCTTTACTAGGAGTATGCCTCATAGTCCAAATTATC ACAGGCCTATTCCTAGCAATACACTACACATCCGACACTTTAACAGCATTC TCATCAGTTACCCACATCTGCCGAGACGTAAACTACGGCTGACTAATCCGA TACTTACACGCCAACGGAGCTTCAATATTCTTTATCTGCCTATTCCTTCATG TAGGACGAGGGATATACTACGGATCCTATACTTTCCTAGAAACATGAAACATTGGA

\section{Talaud Haplotype 2}

TGATGAAATTTTGGCTCTTTACTAGGAGTATGCCTCATAGTCCAAATTATC ACAGGCCTATTCCTAGCAATACACTACACATCCGACACTTTAACAGCATTC TCATCAGTTACCCACATCTGCCGAGACGTAAACTACGGCTGACTAATCCGA TACTTACACGCCAACGGAGCTTCAATATTCTTTATCTGCCTATTCCTTCATG TAGGGCGAGGGATATACTACGGATCCTATACTTTCCTAGAAACATGAAACATTGGA

Talaud Haplotype 3

TGATGAAATTTTGGCTCTTTACTAGGAGTATGCCTCATAGTCCAAATTATC ACAGGCCTATTCCTAGCAATACACTACACATCCGACACTTTAACAGCATTC TCATCAGTTACCCACATCTGCCGAGACGTAAACTACGGCTGACTAATCCGAT ACTTACACGCCAACGGAGCTTCAATATTCTTTATCTGCCTATTCCTCCATGTAGG GCGAGGGATATACTACGGATCCTATACTTTCCTAGAAACATGAAACATTGGA

\section{Fragment 3}

\section{Talaud Haplotype 1}

AGGTTATGTACTCCCATGAGGACAAATATCATTCTGAGGGGCCACAGTAATTACAA ACCTATTATCAGCCATCCCCTATATTGGCACCACTCTAGTCGAATGAATC 
Talaud Haplotype 2

AGGTTATGTACTCCCATGAGGACAAATATCATTCTGAGGGGCCACAGTAATTACAA ACCTATTATCAGCCATCCCCTATATTGGCACCACCCTAGTCGAATGAATC

Talaud Haplotype 3

AGGTTATGTACTCCCATGAGGACAAATATCATTCTGAGGGGCCACAGTAATTACAA ACCTATTATCAGCCATCCCCTATATTGGCACCACCCTAGTCGAATGAATC 
This text is taken from The Archaeology of Sulawesi: Current Research on the Pleistocene to the Historic Period, edited by Sue O'Connor, David Bulbeck and Juliet Meyer, published 2018 by ANU Press, The Australian National University, Canberra, Australia.

doi.org/10.22459/TA48.11.2018.14 